\title{
Remediation of Hg-contaminated marine sediments by simultaneous application of enhancing agents and microwave heating (MWH)
}

\author{
Pietro P. Falciglia ${ }^{a *}$, Danilo Malarbì ${ }^{\mathrm{a}}$, Riccardo Maddalena ${ }^{\mathrm{b}}$, Valentina Greco $^{\mathrm{c}}$, Federico G.A. Vagliasindi ${ }^{\mathrm{a}}$ \\ ${ }^{a}$ Department of Civil Engineering and Architecture - University of Catania. Viale A. Doria, 6 - 95125 Catania, Italy \\ ${ }^{b}$ Department of Civil and Environmental Engineering - University of Strathclyde. 75 Montrose Street - G1 $1 X J$ \\ Glasgow, UK \\ ${ }^{c}$ Department of Chemical Sciences - University of Catania. Viale A. Doria, 6 - 95125 Catania, Italy
}

*Corresponding author. E-mail: ppfalci@dica.unict.it

\begin{abstract}
The aim of this work was to investigate Hg removal ability of a novel microwave heating (MWH) treatment for marine sediment remediation enhanced by the application of several agents, biodegradable complexing agent (methylglycinediacetic acid, MGDA), surfactant $\left(\right.$ Tween $^{\circledR} 80$ ), and citric acid. Main results revealed that MWH allowed a very rapid heating $\left(\sim 450{ }^{\circ} \mathrm{C}\right.$ in $\left.7 \mathrm{~min}\right)$ of the irradiated medium. However, without the addition of enhancing agents, a maximum $\mathrm{Hg}$ removal of $\sim 72 \%$ can be achieved. The application of MGDA led to a higher contaminant removal of $\sim 87 \%$ (residual concentration $=5.4 \mathrm{mg} \mathrm{kg}^{-1}$ ). For the treatment including the simultaneous addition of both chelating agent and surfactant, their synergetic action and stripping processes resulted in a very high $\mathrm{Hg}$ removal of $\sim 99 \%$ for an irradiation time of $7 \mathrm{~min}$, corresponding to a residual concentration of $0.56 \mathrm{mg} \mathrm{kg}^{-1}$, which is lower than the Italian regulatory limit of $1 \mathrm{mg} \mathrm{kg}^{-1}$. The use of citric acid resulted in a shortening of the removal kinetics, which allowed the successful application of a shorter remediation time of $5 \mathrm{~min}$. The observed strong passive ability of sediments to convert a microwave irradiation energy into a rapid and large temperature increase undoubtedly represents a key factor in the whole remediation process, making the studied treatment an excellent choice. Kinetic data are suitable for a preliminarily assessment of the effectiveness of clean-up activities, and as basis for future scaling-up studies on $\mathrm{MWH}$ of $\mathrm{Hg}$ contaminated sediments.
\end{abstract}

Keywords: Citric acid, marine sediment, mercury (Hg), microwave heating (MWH), MGDA, non-ionic surfactant. 


\section{Introduction}

Mercury ( $\mathrm{Hg}$ )-contamination of marine sediments is a serious and global scale environmental problem, especially due to its high persistence and toxicity [1,2]. The largest industrial use of $\mathrm{Hg}$ during the $20^{\text {th }}$ century was the chlor-alkali process, which used electrolysis (Hg being the anode) for separating chlorine and sodium from brine [3]. In Europe, one of the largest and most Hg-polluted site is Augusta Bay. It is a semi-enclosed basin with a coastal area of about $30 \mathrm{~km}^{2}$, and is included in the "Augusta - Melilli - Priolo" industrial area (East coast of Sicily). Since the early 50's, it has been affected by marine contamination from chemical industrial and petrochemical plants [4]. Due to its high state of environmental degradation, in 2002 this site was included in the National Remediation Plan by the Italian Environmental Ministry (Law No. 426/1998) [5]. The major environmental concern was due to the emission activities of a chlor-alkali plant with Hg cells, which operated until 2003, causing a severe Hg - contamination of the bottom sediments [6], especially in the southwestern (SW) zone of the bay [7]. The very high Hg-concentration in sediments, by far exceeding the standard limit reported by national and international sediment quality guidelines (SQGs), and its long-term and mutagenic effects, pose a serious risk to the environment and human health [8]. The unsuitability of the traditional management strategies, such as landfill disposal, makes the possibility to remedy Hg-contaminated sediments a key factor in term of social sustainability, and at the same time, a great challenge for scientific communities and society in general $[9,10]$. However marine sediment characteristics (fine texture, low permeability jointly with a high salinity and organic, sulphide and water content) make their remediation using conventional methods very difficult [11]. Limited techniques have been reported to treat heavy metal-contaminated sediments, such as washing, disposal and stabilisation/solidification. However, they have been proved inappropriate, especially for fine grained and low permeable matrices [12]. Fine textures can in fact result in low metal removals since they reduce the effectiveness of contaminant extraction processes in washing treatments, or in low mechanical resistances of stabilised/solidified matrices. Similarly, a high water content generally results in a worsening of the resistance performance of the treated matrices. Electrokinetic (EK) decontamination has been shown as being more suitable but it generally presents low removal efficiencies with high costs due to the sediment high buffering capacity [13], especially in the presence of high Hg-contamination levels [14]. On the contrary, the mineralogical composition of the sediments and the presence of a high water, as moisture content, and high salinity could represent main 
advantages in the microwave (MW) technique application.

In recent years, microwave heating $(\mathrm{MWH})$ has been documented as a rapid and effective technique for the remediation of soils [15-18], aquifers [19] and for the detoxification of several industrial wastes [20,21]. MWH is based on the conversion process of the MW electric field energy adsorbed by the irradiated medium into heat [22]. This leads to an increase of the matrix temperature resulting in thermal desorption processes and/or in a direct local selective vaporization of contaminants if they are much higher polar than soil. Specifically, the higher the dielectric properties of the irradiated medium, the higher the temperature increase achievable by means of MWH [23]. Minerals, generally constituting the coastal sediments [24], could have dielectric properties (dielectric constant and dielectric loss factor) higher than soil minerals (i.e.: silica, clays) [25] and this would represent a key factor for the achievement of the high temperatures needed to activate $\mathrm{Hg}$ thermal removal from sediments. In addition, at the radio frequency of $2.45 \mathrm{GHz}$, water and sodium chloride are excellent MW absorbers, and the high water amount (40 - 50\%) and salinity, generally present in marine sediments, would allow a rapid vapour production able to increase the contaminant removal efficiency due to distillation and subsequent stripping processes [26,27]. Therefore, MWH may provide an alternative technique for $\mathrm{Hg}$-contaminated marine sediment remediation. However, this has never been investigated. Furthermore, high organic matter and sulphide content or the strength of contaminant sediment bonds could limit the Hg-removal mechanisms requiring temperatures higher than $600{ }^{\circ} \mathrm{C}$ [28]. Consequently, the possibility to develop a novel method to lower the temperature at which $\mathrm{Hg}$ can be reduced to below the regulatory limit of $1 \mathrm{mg} \mathrm{kg}^{-1}$, or to maximize the removal efficiency, and consequently reduce energy requirements, $\mathrm{CO}_{2}$ footprints and costs, could represent an important alternative in contaminated sediment treatment activities. In addition, the possibility to use specific agents to enhance the MWH removal mechanisms, especially contaminant stripping by distillation, could be a further advantage. Synthetic chelates, such as ethylenediamine tetraacetic acid (EDTA) or diethylene triamine pentaacetic acid (DTPA), have largely been employed as enhancing agents in washing [29], EK [30-33] or phytoextraction [34] treatments. However, they have a relatively high environmental persistence and toxicity as well as a thermal instability at high temperatures [35]. On the other hand, the methylglycinediacetic acid (MGDA) is a relatively novel chelate, much more biodegradable than others jointly with the essential advantage of having a stable thermal behaviour under a wide range of temperatures [35]. Likewise, surfactants with low toxicity 
and favourable biodegradability, such as Polyoxyethylene (20) sorbitan monooleate, also known as Tween ${ }^{\circledR}$ 80 [36,37], have been extensively used in organic and inorganic contaminant removal treatments $[11,38,39]$. Recently, citric acid (CA) has also be used to enhance conventional thermal applications [28].

The main aim of this study was to investigate at lab- scale the capability of a novel hybrid MWH treatment for the removal of mercury from real contaminated bottom sediments, which includes the use a biodegradable chelate (C) MGDA, surfactant (S) Tween ${ }^{\circledR} 80$ and citric acid (CA). The influence of the enhancing agent contact time and dose on the Hg removal efficiency was also evaluated. Novel findings from experiments are expected to provide useful basic information for future scaling-up and real scale studies on the enhanced MWH treatment for the successful remediation of marine Hg-contaminated sediments.

\section{Materials and Methods}

\subsection{Sediment sampling and characterization}

The contaminated sediments were collected from the SW part of Augusta Bay in April 2014 (Figure 1). After the sampling procedures, the sediments were stored in a sealed refrigerated $\left(-4{ }^{\circ} \mathrm{C}\right)$ box for their transportation to the laboratory. After air-drying $(72 \mathrm{~h})$, sieving $(2 \mathrm{~mm})$ and homogenizing procedures, the sediment physico-chemical features, as well as the contaminant concentration, were evaluated. The density was assessed using the ASTM D854-92 method, while moisture and organic matter were obtained according to the ASTM D2974-14 method. Sediment salinity was measured as total dissolved salts (TDS) at $25^{\circ} \mathrm{C}$ from a sediment aqueous solution. Specifically, 1:5 sediment:deionised water was prepared by adding $20 \mathrm{~g}$ of airdried sediments to $100 \mathrm{~mL}$ deionised water. The solution was then mechanically shaken in a closed system for $30 \mathrm{~min}$ to dissolve soluble salts before measuring TDS by means of a PCE-PHD 1 conductivity meter. Heavy metal concentration, including Hg, was obtained with US-EPA 6020A and 3051A methods, using ICP-MS. PAHs were determined with US-EPA SW 3541, SW 3620 and 8270 methods coupled with GC-MS analysis. Total petrol hydrocarbon (TPH) concentration was measured by GC-MS using the US-EPA 8270-C method. The concentration of all contaminants was expressed as $\mathrm{mg} \mathrm{kg}_{\mathrm{dw}}{ }^{-1}$.

Mineralogical composition of the sediments was also investigated using $\mathrm{x}$-ray analysis (Bruker AXS D5000), where $\mathrm{Cu}-\mathrm{K} \alpha$ radiation operated at $40 \mathrm{~mA}$ and $45 \mathrm{kV}\left(6-60^{\circ} 2 \theta\right.$ range with a $0.02^{\circ} 2 \theta$ step size and a rate of $\left.0.5 \mathrm{~s} \mathrm{step}^{-1}\right)$. Semi-quantitative analyses on XRD pattern were carried out using a specific MATLAB 
coding. The dielectric features as dielectric constant $\left(\varepsilon^{\prime}\right)$ and dielectric loss factor $\left(\varepsilon^{\prime \prime}\right)$ were measured at the frequency of $2.45 \mathrm{GHz}$ by means of the cavity perturbation method [40]. The mercury fractionation was also obtained by means of modified Tessier sequential extraction procedure [6]. Specifically, five fractions were determined as detailed in Table 1. In order to assess the influence of the sediment salinity on the sediment ability to increase the temperature when irradiated, several sediment samples with a gradual increase in pore water salinity values (from 0 to $10 \%$ and different from the initial natural value of $4.3 \%$ ) were obtained. The procedure included a preliminary sediment washing with deionised water for a complete salinity removal, followed by a different $\mathrm{NaCl}$ dosage to the system [41].

\subsection{Experimental apparatus and procedures}

In this study a MWH treatment (MW) and MWH treatment enhanced by the use of MGDA (MW + C), Tween $^{\circledR} 80(\mathrm{MW}+\mathrm{S})$, their mixture $(\mathrm{MW}+\mathrm{C}+\mathrm{S})$ or citric acid $(\mathrm{MW}+\mathrm{CA})$ were applied to $\mathrm{Hg}-$ contaminated sediment samples. For hybrid treatment tests, MGDA (as $\mathrm{Na}_{3}-\mathrm{MGDA}$ ), Tween ${ }^{\circledR} 80$, MGDA Tween ${ }^{\circledR} 80$ mixture $(1: 1)$ and citric acid were premixed at different concentrations considering a contact time in the 5 - 720 min range. In order to better understand the role of the water amount in Hg-removal mechanisms, MWH tests were also carried out on dried sediment samples (MW - dry). The experimental matrix is given in Table 2. MWH was simulated at lab-scale by means of a dedicated MW setup. It mainly includes an oven cavity where a sediment sample was placed to be irradiated. The cavity was connected by a waveguide to a magnetron able to generate a $2.45 \mathrm{GHz} \mathrm{MW}$ irradiation and operating at the maximum power of $1 \mathrm{~kW}$. A flexible type-k thermocouple $(\varnothing=1.5 \mathrm{~mm})$ was used for recording the sediment sample temperature profiles.. The volatile compounds produced during the treatment were captured by a dedicated exhaust gas line, which consists of a unit for the condensate collecting, an activated carbon filter and an electric vacuum pump. For each test, $25 \mathrm{~g}$ of sediment sample were treated for an irradiation time $(t)$ of 0.5 , $1,3,5$ and $7 \mathrm{~min}$ at a selected power $(P)$ of $0.65 \mathrm{~kW}$. At bench-scale, MW irradiation is generally applied at powers up to a maximum value of $1000 \mathrm{~W}$, which is generally required to totally remove organic pollutants from soils [26]. The temperature variation was also obtained for MW treatment (irradiation time $=3 \mathrm{~min}$ ) of sediments as a function of their pore water salinity. After the treatment, the sediment samples were cooled down, then stored sealed at $-4{ }^{\circ} \mathrm{C}$ before analysis. Residual moisture values, sediment sample temperature profiles and $\mathrm{Hg}$ residual concentrations $(C)$ as $\mathrm{mg} \mathrm{kg}_{\mathrm{dw}}{ }^{-1}$ were obtained for each condition investigated. To 
better comprehend the effect of the single MWH treatments on the Hg removal mechanisms, $\mathrm{Hg}$ sequential extraction of the sediments after their MW irradiation at 7 min was also conducted. Contaminant removal $(R)$ was calculated according to the following expression:

$$
\mathrm{R}_{\%}=\frac{\mathrm{C}_{0}-\mathrm{C}}{\mathrm{C}_{0}} \cdot 100
$$

where $C_{0}$ is the initial $\mathrm{Hg}$ concentration. Triplicated tests were carried out for each condition and mean values were reported. During MWH, hundreds of $\mathrm{Hg}$ species can be obtained from thermal desorption of Hgcontaminated matrices (even if in absence of chelant agents or surfactants), and this makes the development and application of dedicated tools strictly needed to obtain their identification [42]. The addition of compounds such as MGDA, Tween ${ }^{\circledR} 80$ or citric acid and, over all, the use of real contaminated sediment samples, would make the problem even more complex. Total $\mathrm{Hg}$ amount in the condensate and filters were obtained using ICP-MS analysis.

\section{Results and discussion}

\subsection{Sediment characterization and $\mathrm{Hg}$-speciation}

Results from sediment characterization are reported in Table 3. Data confirm a high moisture of $\sim 42 \%$ and a high content of organic matter $(7.4 \mathrm{wt} \%)$ and sulphides $\left(43.6 \mathrm{mg} \mathrm{kg}^{-1}\right)$. The mineralogical composition showed calcite $\left(\mathrm{CaCO}_{3}\right)$, as dominant phase $(70.5 \%)$, quartz $\left(\mathrm{SiO}_{2}\right)(19.5 \%)$ and other silicates, among which montmorillonite, muscovite and illite $(8.8 \%)$. The sediments included a predominant biogenic component $(\mathrm{MgO}+\mathrm{CaO})$ with $\mathrm{SiO}_{2}, \mathrm{Al}_{2} \mathrm{O}_{3}$ and $\mathrm{Fe}_{2} \mathrm{O}_{3}$ as major costituents [24]. From grain size analysis, sediments are classified as silt due to the concentration of silt higher than $88 \%$. The high pore water salt concentration of $4.3 \%$ also confirmed the high salinity of the marine sediments. Contamination analysis revealed a high $\mathrm{Hg}$ concentration of $43.2 \mathrm{mg} \mathrm{kg}^{-1}$, whereas PAH and TPH levels of 2.45 and $6.34 \mathrm{mg} \mathrm{kg}^{-1}$ were detected, respectively. PAH, TPH and heavy metal concentrations were below the Italian regulatory limits, whereas the $\mathrm{Hg}$ level was much higher than the limit of $1 \mathrm{mg} \mathrm{kg}^{-1}$. Physical characterization and the nature of the contamination found are consistent with characteristics of coastal sediments of the SW zone of Augusta Bay $[4,24,43]$. In terms of dielectric properties, the observed relatively high dielectric constant $\left(\varepsilon^{\prime}\right)$ and loss factor $\left(\varepsilon^{\prime \prime}\right)$ of 11.3 and 0.6 , respectively, are due to the high percentage of $\mathrm{CaCO}_{3}$ and the presence of $\mathrm{Al}$ and $\mathrm{Fe}$ oxides in the sediment composition. These compounds are known to have dipolar features much 
higher than minerals, such as $\mathrm{SiO}_{2}$, which generally constitute sandy or silty soils [25]. $\mathrm{CaCO}_{3}, \mathrm{Fe}_{2} \mathrm{O}_{3}$ and $\mathrm{Al}_{2} \mathrm{O}_{3}$ were shown to have $\varepsilon "$ values $\sim 3, \sim 20$ and $\sim 30$ fold higher than $\mathrm{SiO}_{2}$ [44]. Table 4 shows the relative distribution of $\mathrm{Hg}$-fractions assessed by sequential extraction procedure. $\mathrm{Hg}$-carbonate (50.5\%), $\mathrm{Hg}$-organic (36.3\%) and Hg-sulphides $(10.3 \%)$ were found to be the major fractions. This is in agreement with the findings of Orecchio and Polizzotto [6]. Observed Hg-speciation further confirms that Hg-removal is a main challenge and its removal processes using conventional chemical-physical techniques could be strictly inhibited [30]. On the other hand, the high water amount and dielectric properties of sediments could make MWH a perfect candidate to successfully desorb $\mathrm{Hg}$ from marine sediments.

\subsection{MWH and enhanced MWH treatments}

\subsubsection{Sediment temperature profiles}

The sediment temperature $(T)$ profiles with time, recorded for each experimental condition investigated, are given in Figure 2. In all cases, results showed an increase in $T$ with time, due to the capacity of the irradiated samples to absorb the energy of the electric field generated by MW irradiation and convert it into heat. Fundamentals on MWH report that temperature increase ratio is proportional to the loss factor $(\varepsilon ")$ of the irradiated matrix [45], and this is confirmed by the linear increase of temperature observed for sediment samples pre-dried before the MWH treatment. In this case, the maximum $T$ of about $450{ }^{\circ} \mathrm{C}$ was recorded at the end of the irradiation, which highlighted that the presence of higher polar compounds, respect to those observed for soils, resulted in a more rapid temperature increase. Specifically, after the same remediation time, a maximum temperature of about $160{ }^{\circ} \mathrm{C}$ was observed for MW treatment of sandy soils. Much lower temperatures were observed in the case of silty or clayey soils. In any case, temperatures not higher than $\sim 270{ }^{\circ} \mathrm{C}$ were found also with higher operating powers, up to $1.0 \mathrm{~kW}$, and much longer times, up to $60 \mathrm{~min}$ [25]. For all the moisturised sediment treatments, at the beginning of the MW irradiation, the $T$ increase was limited by the presence of water, due to the higher energy required for its evaporation. Specifically, the sediment temperature kept constant at $\sim 100{ }^{\circ} \mathrm{C}$ between 0.5 and $2.0 \mathrm{~min}$, until almost all the water evaporated (Table 4). However, final temperatures in the range $422-437{ }^{\circ} \mathrm{C}$ (not much lower than that found for dry sediments) were observed. No relevant differences between the treatments with or without enhancing agent addition were found. Overall, the observed strong passive ability of sediments to convert a relatively low power irradiation energy into a rapid and large temperature increase (maximum $T$ increase rate 
of $\sim 64{ }^{\circ} \mathrm{C} \mathrm{min}^{-1}$ ) undoubtedly represents a key factor in the whole remediation process. This also depended on the high salinity, in addition to the large concentration of calcite in the mineralogical composition of the sediments, as confirmed by investigated influence of sediment salinity on T variation (Figure 3). An almost linear $\mathrm{T}$ increase was in fact found with sediment pore water salinity up to the value of $4.3 \%$, which corresponded to the natural salinity content. Higher salinity values did not lead to a further $\mathrm{T}$ increase. At the frequency of $2.45 \mathrm{GHz}$, sodium chloride was shown to have dielectric properties higher than those of soil or sediment minerals, which also greatly increase for temperatures higher than $90{ }^{\circ} \mathrm{C}$. This allowed a relevant increase in the dielectric constants of geological materials respect to increasing values of salinity $[46,47]$.

\subsubsection{Hg removal kinetics in unenhanced treatments}

Figure 4 shows the $\mathrm{Hg}$ residual concentration $(C)$ in sediments after MW treatments at different irradiation times. Results were observed to have a maximum error of $\pm 5.8 \%$. As expected, $C$ decreased with $t$ for all the treatments, and the rate of removal strictly depended on the specific treatment applied and the temperature profile achieved. In the case of irradiation of dried sediment samples, $C$ was higher than $29 \mathrm{mg} \mathrm{kg}^{-1}$, corresponding to a percentage removal $(R)$ of $\sim 33 \%$, when the temperature was below $162{ }^{\circ} \mathrm{C}(t=2 \mathrm{~min})$. When $T$ was higher than $233{ }^{\circ} \mathrm{C}, C$ dramatically decreased up to a minimum value of $15 \mathrm{mg} \mathrm{kg}^{-1}(R=$ 65.3\%), which was found for the highest observed $T$ of $452{ }^{\circ} \mathrm{C}(t=7 \mathrm{~min})$. The increase in temperature resulted in Hg-thermal desorption phenomena also capable of destroying forces existing between the contaminant and sediments. Lower $C$ values were generally observed for the moisturised sediment samples. In this case, $C$ was higher than $15.6 \mathrm{mg} \mathrm{kg}^{-1}(R=\sim 64 \%)$ when the temperature was below $192{ }^{\circ} \mathrm{C}(t=3$ $\mathrm{min})$, whereas it decreased to its minimum value of $12.6 \mathrm{mg} \mathrm{kg}^{-1}(R=\sim 72 \%)$ when $T$ was $437^{\circ} \mathrm{C}(t=7 \mathrm{~min})$. During MWH, the water in the moisturised sediments changed its phase into vapour. This produced an additional $\mathrm{Hg}$ removal action due to the activation of stripping processes, which moved mercury from the sediment to the gas phase, leading to a greater $\mathrm{Hg}$ removal [48]. In the presence of pore-water, a thermal treatment may produce an entrainment gas stream, which enhances the removal of $\mathrm{Hg}$ gas phase and other compounds that are not normally considered volatile [42]. The improved effectiveness of the MWH can be also ascribable to the increase in the sediment permeability caused by the vapour hot flow, which provides uniform vapour flow patterns for superheated mercury in fine texture matrices [42]. Results also showed a progressive reduction in the slope of $\mathrm{Hg}$ removal kinetics, which is typical for conventional thermal 
desorption treatments [49]. However, it was also due to the progressive reduction of the residual water content observed during the MWH (Table 4). The higher removal efficiencies found for the moisturised sediments respect to the dry ones, clearly highlighted that the $\mathrm{Hg}$ removal process is strongly enhanced by the water as sediment moisture $[18,26]$. This was also verified by the high removal observed for the F1 fraction (Table 5). The relatively low removals achievable at the end of the unenhanced MW treatment mainly depended on the high percentage of carbonates, organic matter and sulphides (Table 3), which resulted in tight bounds with mercury [42], as confirmed by the Hg residual concentrations of 3.33 (27.2\%), $4.42(36.1 \%)$ and $4.02 \mathrm{mg} \mathrm{kg}^{-1}(32.8 \%)$ in the carbonate, organic/metallic and sulphides fractions, respectively (Table 5). $\mathrm{Hg}(\mathrm{II})$ forms extremely strong complexes with organic matter adsorbed onto the sediment surface [50] and reduced sulphur [14], affecting $\mathrm{Hg}$ transport and removal mechanisms. Temperatures higher than $500{ }^{\circ} \mathrm{C}$ can be required to convert compounds such as $\mathrm{HgS}$ and $\mathrm{HgCO}_{3}$ into gaseous elemental mercury [51]. Ma et al. [28] reported that organic carbon in Hg-contaminated soils treated at $400{ }^{\circ} \mathrm{C}$ was $65 \%$ respect to its initial value, whereas organic carbon was reduced to $0.02 \%$ after a heating at $700{ }^{\circ} \mathrm{C}$. These findings indicate that irradiation alone can't effectively reduce residual $\mathrm{Hg}$ to levels below the maximum allowed concentration. Results are in agreement with those from previous studies. Ma et al. [52] found a $\mathrm{Hg}$ soil concentration reduction from $\sim 70$ to $11 \mathrm{mg} \mathrm{kg}^{-1}$ when treated at $500{ }^{\circ} \mathrm{C}$. Data were also in agreement with Reis et al. [53] and Rumayor et al. [54].

\subsubsection{Hg removal kinetics in enhanced treatments}

The effect of the addition of MGDA on Hg-residual concentration was also assessed and results were compared with the application of MWH only (Figure 4). Data were observed to have a maximum margin of error of $\pm 6.9 \%$. Similar to MW treatment, results showed a clear dependence of $\mathrm{Hg}$ removal on the related sediment temperature profile. Specifically, after 2 min of MGDA - enhanced treatment $(M W+C)$, a residual $\mathrm{Hg}$ content of $27.2 \mathrm{mg} \mathrm{kg}^{-1}$ was observed, whereas a further decrease up to 12.1, 7.7 and 5.4 was achieved for longer times of 3, 5 and $7 \mathrm{~min}$, respectively. Observed residual concentrations corresponded to a percentage reduction in the range $10-56 \%$ respect to the MWH without MGDA addition. An improvement in $\mathrm{Hg}$ removal rate depended on synergetic action of both stripping process and $\mathrm{Hg}$ enhanced mobility due to the strong chelating ability of MGDA in forming Me(II)-MGDA stable complexes also in high temperature and wide $\mathrm{pH}$ range environments. More details on MGDA metal chelation mechanisms can be found in 
Jachula et al. [55]. In particular, observed chelating action was found to have a specific action on $\mathrm{Hg}$ bound to carbonates, oxides and sulphides for which a reduction from $3.33,0.44$ and $4.02 \mathrm{mg} \mathrm{kg}^{-1}$ to $0.33,0.20$ and $0.93 \mathrm{mg} \mathrm{kg}^{-1}$ was respectively observed at the end of the test (Table 5). This is in accordance with Peters et al. [56]. Otherwise, no relevant reduction in organo-Hg-complexes was found due to the interference of organic matter with MGDA chelant action [50].

The addition of Tween ${ }^{\circledR} 80$ alone $(\mathrm{MW}+\mathrm{S})$ led to higher residual $\mathrm{Hg}$ values of 27.1, 14.2, 11.1 and $9.0 \mathrm{mg}$ $\mathrm{kg}^{-1}$ after 2, 3, 5 and $7 \mathrm{~min}$ of MW irradiation, respectively (Figure 4). As shown in Table 5, this corresponded to a great reduction $(\sim 65 \%)$ of F4 fraction. This depended on the specific action of Tween ${ }^{\circledR} 80$ on the removal of organo-Hg-complexes. Tween ${ }^{\circledR} 80$ structure includes a lipophilic part with a very high affinity for the organic compounds and a hydrophilic part, which, on the contrary, tends to be attracted by the moisturised mineral particles [57]. Consequently, its addition to the sediments resulted in the solubilisation of the organic matter and its complexes with $\mathrm{Hg}$, which in turn led to an increase of their transfer to the liquid phase [39,57]. On the other hand, limited reduction achieved for F2 (carbonates) and F5 (sulphides) remarks that their removal strictly depends on the activation of complexation and/or ionic exchange processes. However, these require the ionic nature of the surfactant. Another reason for the low $\mathrm{Hg}$ removals observed could be the temperature dependent behaviour of the Tween ${ }^{\circledR} 80$, which tends to loose its hydrophilic character at high temperatures [37]. In both cases (MGDA or Tween ${ }^{\circledR} 80$ ), results again revealed residual $\mathrm{Hg}$ levels higher than the regulatory limit.

When Tween ${ }^{\circledR} 80$ and MGDA were simultaneously added (MW $+\mathrm{S}+\mathrm{C}$ ), an enhancement of the solubilisation removal mechanisms was observed due to their synergetic action. This led to a final residual $\mathrm{Hg}$ concentration of $0.56 \mathrm{mg} \mathrm{kg}^{-1}(\mathrm{R}=99 \%)$ (Figure 4), which allowed the regulatory limit to be met. A corresponding strong reduction of all $\mathrm{Hg}$ fractions investigated was also observed (Table 5). A probable reason is the improvement of the $\mathrm{Hg}$ chelant action of MGDA due to the specific action of the surfactant on the removal of organic matter and F4 fraction (Table 5), which are known to reduce the chelant action [50,58]. Chelating agents were shown to be very good synergists in combined use with surfactants. In this case, the addition of MGDA to Tween ${ }^{\circledR} 80$ also gave it an ionic behaviour, which then, acted as an ionic surfactant with the advantages of the non-ionic one (i.e.: low critic micelle concentration and lipophilic behavior) [39]. 
When the citric acid was added to the sediments $(\mathrm{MW}+\mathrm{CA})$, a general remarkable improvement of $\mathrm{Hg}$ removal was observed (Figure 4). This allowed the achievement of a residual $\mathrm{Hg}$ concentration lower than the limit of $1 \mathrm{mg} \mathrm{kg}^{-1}(\mathrm{R}=99 \%)$ in a shorter irradiation time of 5 min. kinetic also exhibited a higher slop respect to all previous cases between 1 and $2 \mathrm{~min}$, which corresponded to the duration for which the temperature remained almost constant due to the water evaporation. This probably indicated that a different $\mathrm{Hg}$ removal mechanism took place. The addition of chelates or surfactant resulted an improvement of the solubilisation process, which in turn helped $\mathrm{Hg}$ removal by distillation. In this case, the addition of citric acid facilitated the chemical action in destroying the $\mathrm{Hg}$-sediment bounds due to the ability of citric acid to dissolve the $\mathrm{CaCO}_{3}$ [28], which is the main mineral constituent of the sediments and offers adsorption sites for $\mathrm{Hg}$ and organic matter. A total removal of F4 fraction was in fact observed at the end of this treatment (Table 5). Therefore, the presence of citric acid clearly helped $\mathrm{Hg}$ desorption via thermal and stripping processes. Obtained results are in agreement with Hahladakis et al. [38] who reported that metal removal from sediments by EK can be enhanced using citric acid in the anodic chamber due to its strong ability to remove the organic matter and the metals adsorbed onto it.

Total mercury analysis from the off-gas treatment system revealed that for all experiments the overall recovery was in the $88-99 \%$ range. Specifically, the major part was entrapped in the condenser unit $(\sim 74 \%)$, whereas $\sim 26 \%$ was collected by the filtering system. This is in agreement with Kunkel et al. [59]. Although the development of specific models is strictly required for the identification of several $\mathrm{Hg}$ species produced during the treatment, based on literature findings, main $\mathrm{Hg}$ forms that are expected to be found in exhaust gas traps are $\mathrm{Hg}^{0}, \mathrm{HgCl}_{2}, \mathrm{HgO}, \mathrm{Hg}_{2} \mathrm{SO}_{4}$ and $\mathrm{Hg}(\mathrm{OH})_{2}$. $\mathrm{Hg}$ released from mineral bounds, may also generate secondary $\mathrm{Hg}$ phases such as andtiemannite $(\mathrm{HgSe})$, corderoite $\left(\mathrm{Hg}_{3} \mathrm{~S}_{2} \mathrm{Cl}_{2}\right)$, laffittite $(\mathrm{AgHgAsS})$, metacinnabar $(\mathrm{HgS})$, schuetteite $\left(\mathrm{Hg}_{3}\left(\mathrm{SO}_{4}\right) \mathrm{O}_{2}\right)$ and shakhovite $\left(\mathrm{Hg}_{4} \mathrm{SbO}_{5}(\mathrm{OH})_{3}\right)$. However precipitated cinnabar generally represents the predominant phase in solid phase-mercury. At the same time, carbonate minerals decompose to the oxide or basic carbonates with the production of $\mathrm{CO}_{2}$ [42].

\subsubsection{Influence of enhancing agent dose and contact time on MWH effectiveness}

The influence of Tween ${ }^{\circledR}$-MGDA mixture and citric acid dose on the Hg removal kinetics was evaluated for an irradiation time of $3 \mathrm{~min}$ and a contact time of $60 \mathrm{~min}$. Results are given in Figures 5. Data were observed to have a maximum margin of error of $\pm 5.8 \%$ and showed that in $\mathrm{MW}+\mathrm{S}+\mathrm{C}$ treatment any relevant 
variation of temperature or contaminant removal did not occur with increasing the concentration of the enhancing agent. Only a slight difference in evaporation behaviour was recorded between only water and the solutions at 2 and $4 \%$ (Table 4). This was probably due to the increase of the solute concentration in the interstitial solution, which, consequently, would have produced a lowering of the vapour pressure. In terms of $\mathrm{Hg}$ removal, it is clear that the increase in agent amount, from 2 to $4 \%$ did not enhance the performance of the system. On the other hand, a marked increase in Hg removal was observed when the citric acid dose increased from 0.1 to $0.2 \mathrm{M}(\mathrm{MW}+\mathrm{CA})$ (Figure 6). However, a further increase to 0.3 did not lead to higher Hg removals. Again, no variation of temperature occurred with increasing the citric acid dose. Obtained findings highlighted that $2 \%$ and $0.2 \mathrm{M}$ can be considered as optimal doses for Tween ${ }^{\circledR}$-MGDA mixture and citric acid, respectively.

Results also demonstrated that in $\mathrm{MW}+\mathrm{S}+\mathrm{C}(2 \%)$ and $\mathrm{MW}+\mathrm{CA}(0.2 \mathrm{M})$ treatments the variation of the enhancing agent contact time influenced the $\mathrm{Hg}$ removal process (Figure 7). In both cases, an increase in $\mathrm{Hg}$ removal was found when contact time increased from 5 to 60 min. Higher contact times did not result in an improvement of the performance of the system. This confirms that $1 \mathrm{~h}$ is a sufficient time because the enhancing chemical reactions, described in the previous section, took place resulting in the maximum $\mathrm{Hg}$ removal rate. This is in agreement with other studies [60,61] investigating the effect of surfactant or chelant contact time on Hg removal.

\subsection{Comparison to other clean-up alternatives}

An almost total Hg removal from sediments observed in such a short time is hardly achievable by other remediation techniques, which often require multi-step processes. This is also due to the features of the studied treatment that acted simulating a high effective multi-step process, where a pure thermal desorption (after drying) is followed by an initial combined sediment washing and thermal desorption treatment. A further advantage respect to conventional sediment treatments is that there is neither need for initial water addition nor to treat the final wastewater containing the by-products of the contaminant removal. In addition, the heating process allows a very effective dewatering treatment, strictly required as pre-treatment for marine sediment decontamination. Generally, centrifuges, filter presses, plate or diaphragm-plate filter or gravity thickening can be used for dewatering purposes; however, these methods are not suitable for silt or clay [62]. 
Results from a study by He et al. [63] showed that ultrasound and alga biomass (2AMT-2) combined technique was effective to remove $\sim 24 \%$ of mercury from sediments with a certified initial content of 3.04 $\mathrm{mg} \mathrm{kg}^{-1}$. Careghini et al. [43] reported a maximum $\mathrm{Hg}$ removal of $63 \%$ from marine sediments dredged from Augusta Bay applying a sequential S/S and thermal process for $4 \mathrm{~h}$. Similar removals were found by Comuzzi et al. [64] testing a decontamination procedure of Hg-polluted dredged sludge from Marano-Grado Lagoon (NE Italy), based on cationic exchange associated with low temperature thermal desorption. $\mathrm{Hg}$ removals between 24 and $60 \%$ were observed when the samples were treated with a $15 \%$ solution of tetrabutyl-ammonium chloride. The range depended on the nature of the slurry (Hg pollution ranging from 20 to 200 ppm). Relatively low Hg removal was also found by treating marine sediments with EK despite the initial $\mathrm{Hg}$ content being very low $\left(1.17 \mathrm{mg} \mathrm{kg}^{-1}\right)$ [11]. Authors reported the highest removal of $\sim 46 \%$ when EK was applied for 30 days (voltage $=3 \mathrm{~V} \mathrm{~cm}^{-1}$ ) using $\mathrm{H}_{2} \mathrm{O}_{2}$ and EDTA solution as processing fluids. More recently, Falciglia et al. [65] reported that a 400-h EK treatment led to a limited $\mathrm{Hg}$ removal of $\sim 71 \%$, which did not match with the desired regulatory limit for Augusta bay. Literature has demonstrated that only conventional thermal treatments can be effective, but require high temperatures and fuel costs in the range of US\$ $650-1000$ ton $^{-1}[1,62]$. On the other hand, recent literature [66] demonstrated that low energy costs in the $18-27 €$ ton $^{-1}$ range are required in MWH treatments of contaminated soils. Because MWH was shown to be more effective in sediment remediation rather than soils, obtained results make MWH a potential costeffective alternative to conventional thermal desorption.

\section{Conclusions}

Based on results obtained from experiments, the following conclusions can be drawn:

- Simulated MWH allowed the achievement of a very rapid heating (maximum $\Delta T$ rate $=\sim 64{ }^{\circ} \mathrm{C} \min ^{-}$ ${ }^{1}$ ) and high sediment temperature (maximum $T=\sim 450^{\circ} \mathrm{C}$ ), mainly due to the mineral composition of the sediments and high salinity, and consequently, their dielectric properties, which were much higher than those generally observed for soils. No relevant differences of temperature between treatments with or without enhancing agent addition were found. In addition the heating process allowed a very rapid and effective dewatering, strictly required as pre-treatment for marine sediment decontamination. 
- For the MWH without enhancing agent addition, relatively low $\mathrm{Hg}$ removals were achieved. In this case, $\mathrm{Hg}$ removal is activated by thermal desorption and stripping processes. Specifically, a residual concentration of $15.6(R=\sim 64 \%)$ and $12.6 \mathrm{mg} \mathrm{kg}^{-1}(R=\sim 72 \%)$ was found after a 3 or $7 \mathrm{~min}$ irradiation time, respectively. The application of MGDA led to a further $\mathrm{Hg}$ concentration reduction in the range $10-56 \%$, due to the MGDA chelating ability, with minimal value of $5.4 \mathrm{mg} \mathrm{kg}^{-1}(R=$ $\sim 87 \%$ ) being achieved for longest time investigated. Lower Hg-removals were observed for the surfactant enhanced MWH. For the treatment including the simultaneous addition of both the enhancing additives (chelating agent + surfactant), their synergetic action and stripping processes led to a very low residual $\mathrm{Hg}$ concentration of $0.56 \mathrm{mg} \mathrm{kg}^{-1}$ after 7-min treatment, corresponding to a contaminant removal of $\sim 99 \%$. The addition of citric acid resulted in a remarkable improvement of $\mathrm{Hg}$ removal kinetics, which allows the achievement of a residual $\mathrm{Hg}$ concentration lower than the limit of $1 \mathrm{mg} \mathrm{kg}^{-1}$ in a shorter irradiation time of $5 \mathrm{~min}$.

- None relevant variation of temperature or contaminant removal occurred with increasing the concentration of the Tween ${ }^{\circledR}$ - MGDA mixture from 2 to $4 \%$. On the other hand, a marked increase in $\mathrm{Hg}$ removal was observed when the citric acid dose increased from 0.1 to $0.2 \mathrm{M}$. However, a higher citric acid dose did not lead to higher $\mathrm{Hg}$ removals. Obtained findings highlighted that $2 \%$ and $0.2 \mathrm{M}$ can be considered as optimal doses for Tween ${ }^{\circledR}$-MGDA mixture and citric acid, respectively. Results also exhibited that in $\mathrm{MW}+\mathrm{S}+\mathrm{C}$ and $\mathrm{MW}+\mathrm{CA}$ treatments the variation of the enhancing agent contact time influenced the $\mathrm{Hg}$ removal. In both cases, a contact time of $1 \mathrm{~h}$ can be considered as optimal.

- Achieved Hg removals in such a short time are hardly possible by other remediation techniques. This is also due to the features of the enhanced MWH that operated as a high effective multi-step technique (washing + pure thermal desorption). The observed strong passive ability of sediments to convert a low power irradiation energy into a rapid and large temperature increase undoubtedly represents a key factor in the whole remediation process, potentially able to reduce the energy costs. A further advantage is that there is no need to treat the final wastewater for by-product removal.

- Observed kinetic data can be suitable for the preliminarily assessment of the effectiveness of cleanup activities for contaminated sediment remediation. The investigated Hg-removal mechanisms can 
also serve as basis for future scaling-up works on enhanced MWH of Hg-contaminated sediments or

for the creation of novel hybrid techniques based on MW irradiation processes.

\section{References}

[1] A. Akcil, C. Erust, S. Ozdemiroglu, V. Fonti, F. Beolchini, A review of approaches and techniques used in aquatic contaminated sediments: Metal removal and stabilization by chemical and biotechnological processes, J. Clean. Prod. 86 (2015) 24-26. doi:10.1016/j.jclepro.2014.08.009.

[2] T.R. Walker, J. Grant, Metal(loid)s in sediment, lobster and mussel tissues near historical gold mine sites, Mar. Pollut. Bull. 101 (2015) 404-408. doi:10.1016/j.marpolbul.2015.10.010.

[3] T.R. Walker, Mercury concentrations in marine sediments near a former mercury cell chlor-alkali plant in eastern Canada, Mar. Pollut. Bull. 107 (2015) 398-401. doi:10.1016/j.marpolbul.2016.03.033.

[4] R. Di Leonardo, G. Adelfio, A. Bellanca, M. Chiodi, S. Mazzola, Analysis and assessment of trace element contamination in offshore sediments of the Augusta Bay (SE Sicily): A multivariate statistical approach based on canonical correlation analysis and mixture density estimation approach, J. Sea Res. 85 (2014) 428-442. doi:10.1016/j.seares.2013.07.015.

[5] M. Maisano, T. Cappello, A. Natalotto, V. Vitale, V. Parrino, A. Giannetto, S. Oliva, G. Mancini, S. Cappello, A. Mauceri, S. Fasulo, Effects of petrochemical contamination on caged marine mussels using a multi-biomarker approach: Histological changes, neurotoxicity and hypoxic stress, Mar. Environ. Res. (2015) 1-10. doi:10.1016/j.marenvres.2016.03.008.

[6] S. Orecchio, G. Polizzotto, Fractionation of mercury in sediments during draining of Augusta (Italy) coastal area by modified Tessier method, Microchem. J. 110 (2013) 452-457. doi:10.1016/j.microc.2013.05.015.

[7] E. Oliveri, D. Salvagio, M. Bonsignore, S. Cappello, G. Tranchida, E. Bagnato, N. Sabatino, S. Santisi, M. Sprovieri, Mobility of mercury in contaminated marine sediments: Biogeochemical pathways, Mar. Chem. 186 (2016) 1-10. doi:10.1016/j.marchem.2016.07.002.

[8] M. Bonsignore, N. Andolfi, M. Barra, A. Madeddu, F. Tisano, V. Ingallinella, M. Castorina, M. Sprovieri, Assessment of mercury exposure in human populations: A status report from Augusta Bay (southern Italy), Environ. Res. 150 (2016) 592-599. doi:10.1016/j.envres.2016.01.016.

[9] M. Bonsignore, S. Tamburrino, E. Oliveri, A. Marchetti, C. Durante, A. Berni, E. Quinci, M. Sprovieri, Tracing mercury pathways in Augusta Bay (southern Italy) by total concentration and isotope determination., Environ. Pollut. 205 (2015) 178-85. doi:10.1016/j.envpol.2015.05.033.

[10] J. Pinedo-Hernández, J. Marrugo-Negrete, S. Díez, Speciation and bioavailability of mercury in sediments impacted by gold mining in Colombia, Chemosphere. 119 (2015) 1289-1295. doi:10.1016/j.chemosphere.2014.09.044.

[11] M. Pazos, O. Iglesias, J. Gomez, E. Rosales, M.A. Sanroman, Remediation of contaminated marine sediment using electrokinetic-Fenton technology, J. Ind. Eng. Chem. 19 (2013) 932-937. doi:10.1016/j.jiec.2012.11.010.

[12] J.N. Hahladakis, W. Calmano, E. Gidarakos, Use and comparison of the non-ionic surfactants Poloxamer 407 and Nonidet P40 with HP- $\beta-C D$ cyclodextrin, for the enhanced electroremediation of real contaminated sediments from PAHs, Sep. Pur. Tecnol. 113 (2013) 104-113.

[13] A. Colacicco, G. De Gioannis, A. Muntoni, E. Pettinao, A. Polettini, R. Pomi, Enhanced electrokinetic treatment of marine sediments contaminated by heavy metals and PAHs, Chemosphere. 81 (2010) 46-56. doi:10.1016/j.chemosphere.2010.07.004.

[14] P.M. Randall, S. Chattopadhyay, Mercury contaminated sediment sites-An evaluation of remedial options, Environ. Res. 125 (2013) 131-149. doi:10.1016/j.envres.2013.01.007. 

evaluation of a continuous microwave processing system for hydrocarbon removal from solids, Chem. Eng. J. 283 (2016) 215-222. doi:10.1016/j.cej.2015.07.030.

[16] P.P. Falciglia, F.G.A. Vagliasindi, Remediation of hydrocarbon-contaminated soils by ex situ microwave treatment: technical, energy and economic considerations, Environ. Technol. 35 (2014) 2280-2288. doi:10.1080/09593330.2014.902109.

[17] P.P. Falciglia, F.G.A. Vagliasindi, Techno-economic analysis of hydrocarbon-polluted soil treatment by using ex situ microwave heating: influence of soil texture and soil moisture on electric field penetration, operating conditions and energy costs, J. Soils Sediments. 16 (2015) 1330-1344. doi:10.1007/s11368-015-1130-6.

[18] P.P. Falciglia, G. De Guidi, A. Catalfo, F.G.A. Vagliasindi, Remediation of soils contaminated with PAHs and nitro-PAHs using microwave irradiation, Chem. Eng. J. 296 (2016) 162172. doi:10.1016/j.cej.2016.03.099.

[19] P.P. Falciglia, R. Maddalena, G. Mancuso, V. Messina, F.G.A. Vagliasindi, Lab-scale investigation on remediation of diesel-contaminated aquifer using microwave energy, J. Environ. Manage. 167 (2016) 196-205. doi:10.1016/j.jenvman.2015.11.046.

[20] M. Al-harahsheh, S. Kingman, L. Al-Makhadmah, I.E. Hamilton, Microwave treatment of electric arc furnace dust with PVC: Dielectric characterization and pyrolysis-leaching, J. Hazard. Mater. 274 (2014) 87-97. doi:10.1016/j.jhazmat.2014.03.019.

[21] M.S. Pereira, C.M.D.Á. Panisset, A.L. Martins, C.H.M. De Sá, M.A.D.S. Barrozo, C.H. Ataíde, Microwave treatment of drilled cuttings contaminated by synthetic drilling fluid, Sep. Purif. Technol. 124 (2014) 68-73. doi:10.1016/j.seppur.2014.01.011.

[22] M.W. Lim, E. Von Lau, P.E. Poh, A comprehensive guide of remediation technologies for oil contaminated soil - Present works and future directions, MPB. (2016). doi:10.1016/j.marpolbul.2016.04.023.

[23] P.P. Falciglia, G. Mancuso, P. Scandura, F.G.A. Vagliasindi, Effective decontamination of low dielectric hydrocarbon-polluted soils using microwave heating: Experimental investigation and modelling for in situ treatment, Sep. Purif. Technol. 156 (2015) 480-488. doi:10.1016/j.seppur.2015.10.038.

[24] R. Di Leonardo, A. Mazzola, C.D. Tramati, A. Vaccaro, S. Vizzini, Highly contaminated areas as sources of pollution for adjoining ecosystems: The case of Augusta Bay (Central Mediterranean), Marine Pollution Bulletin $89 \quad$ (2014) 417-426. http://dx.doi.org/10.1016/j.marpolbul.2014.10.023.

[25] P.P. Falciglia, F.G.A. Vagliasindi, Remediation of hydrocarbon polluted soils using $2.45 \mathrm{GHz}$ frequency-heating: Influence of operating power and soil texture on soil temperature profiles and contaminant removal kinetics, J. Geochemical Explor. 151 (2015) 66-73. doi:10.1016/j.gexplo.2015.01.007.

[26] P.P. Falciglia, G. Urso, F.G.A. Vagliasindi, Microwave heating remediation of soils contaminated with diesel fuel, J. Soils Sediments. 13 (2013) 1396-1407. doi:10.1007/s11368-013-0727$\mathrm{x}$.

[27] J. Robinson, E. Binner, A. Saeid, M. Al-Harahsheh, S. Kingman, Microwave processing of Oil Sands and contribution of clay minerals, Fuel. 135 (2014) 153-161. doi:10.1016/j.fuel.2014.06.057.

[28] F. Ma, C. Peng, D. Hou, B. Wu, Q. Zhang, F. Li, Q. Gu, Citric acid facilitated thermal treatment: An innovative method for the remediation of mercury contaminated soil, J. Hazard. Mat. 300 (2015) 546-552. http://dx.doi.org/10.1016/j.jhazmat.2015.07.055.

[29] X. Guo, Z. Wei, Q. Wu, C. Li, T. Qian, W. Zheng, Effect of soil washing with only chelators or combining with ferric chloride on soil heavy metal removal and phytoavailability: Field experiments, Chemosphere. 147 (2016) 412-419. doi:10.1016/j.chemosphere.2015.12.087. 
[30] K.J. Kim, D.H. Kim, J.C. Yoo, K. Baek, Electrokinetic extraction of heavy metals from dredged marine sediment, Sep. Purif. Technol. 79 (2011) 164-169. doi:10.1016/j.seppur.2011.02.010.

[31] I. Robles, M.J. Lozano, S. Solis, G. Hernandez, M. V. Paz, M.G. Olvera, et al., Electrokinetic Treatment of Mercury-Polluted Soil Facilitated by Ethylenediaminetetraacetic Acid Coupled with A Reactor with A Permeable Reactive Barrier of Iron to Recover Mercury (II) from Water, Electrochim. Acta. 181 (2015) 68-72. doi:10.1016/j.electacta.2015.04.099.

[32] L. Rajić, B. Dalmacija, M. Dalmacija, S. Rončević, S. Ugarčina Perović, Enhancing electrokinetic lead removal from sediment: Utilizing the moving anode technique and increasing the cathode compartment length, Electrochim. Acta. 86 (2012) 36-40. doi:10.1016/j.electacta.2012.02.029.

[33] F. Rozas, M. Castellote, Electrokinetic remediation of dredged sediments polluted with heavy metals with different enhancing electrolytes, Electrochim. Acta. 86 (2012) 102-109. doi:10.1016/j.electacta.2012.03.068.

[34] P. Fine, R. Paresh, A. Beriozkin, A. Hass, Chelant-enhanced heavy metal uptake by Eucalyptus trees under controlled deficit irrigation, Sci. Total Environ. 493 (2014) 995-1005. doi:10.1016/j.scitotenv.2014.06.085.

[35] I. González, A. Cortes, A. Neaman, P. Rubio, Biodegradable chelate enhances the phytoextraction of copper by Oenothera picensis grown in copper-contaminated acid soils, Chemosphere. 84 (2011) 490-496. doi:10.1016/j.chemosphere.2011.03.015.

[36] D. Huguenot, E. Mousset, E.D. van Hullebusch, M.A. Oturan, Combination of surfactant enhanced soil washing and electro-Fenton process for the treatment of soils contaminated by petroleum hydrocarbons, J. Environ. Manage. 153 (2015) 40-47. doi:10.1016/j.jenvman.2015.01.037.

[37] C. Prieto, L. Calvo, Performance of the Biocompatible Surfactant Tween 80, for the Formation of Microemulsions Suitable for New Pharmaceutical Processing, J. Appl. Chem. 2013 (2013) 1-10. doi:10.1155/2013/930356.

[38] J.N. Hahladakis, N. Lekkas, A. Smponias, E. Gidarakos, Sequential application of chelating agents and innovative surfactants for the enhanced electroremediation of real sediments from toxic metas and PAHs, Chemosphere 105 (2014) 44 - 52.

[39] X. Mao, R. Jiang, W. Xiao, J. Yu, Use of surfactants for the remediation of contaminated soils: A review, J. Hazard. Mater. 285 (2015) 419-435. doi:10.1016/j.jhazmat.2014.12.009.

[40] J.P. Robinson, S.W. Kingman, E.H. Lester, C. Yi, Microwave remediation of hydrocarboncontaminated soils - Scale-up using batch reactors, Sep. Purif. Technol. 96 (2012) 12-19. doi:10.1016/j.seppur.2012.05.020.

[41] G. Di Bella, N. Di Prima, D. Di Trapani, G. Freni, M.G. Giustra, M. Torregrossa, G. Viviani, Performance of membrane bioreactor (MBR) systems for the treatment of shipboard slops: Assessment of hydrocarbon biodegradation and biomass activity under salinity variation, J. Hazard. Mater. 300 (2015) 765-778. doi:10.1016/j.jhazmat.2015.08.021.

[42] C.M. Park, L.E. Katz, H.M. Liljestrand, Mercury speciation during in situ thermal desorption in soil, J. Hazard. Mater. 300 (2015) 624-632. doi:10.1016/j.jhazmat.2015.07.076.

[43] A. Careghini, S. Dastoli, G. Ferrari, S. Saponaro, L. Bonomo, L. De Propris, M. Gabellini, Sequential solidification/stabilization and thermal process under vacuum for the treatment of mercury in sediments, J. Soils Sediments. 10 (2010) 1646-1656. doi:10.1007/s11368-010-0290-7.

[44] R.J. Sengwa, A. Soni, Dielectric properties of some minerals of western Rajasthan, Indian J. Radio Sp. Phys. 37 (2008) 57-63.

[45] J.P. Robinson, S.W. Kingman, C.E. Snape, H. Shang, R. Barranco, A. Saeid, Separation of polyaromatic hydrocarbons from contaminated soils using microwave heating, Sep. Purif. Technol. 69 (2009) 249-254. doi:10.1016/j.seppur.2009.07.024.

[46] Y. Lasne, P. Paillou, G. Ruffié, C. Serradilla, A. Freeman, T. Farr, K. Mcdonald, B. Chapman, Effect of Salinity on the Dielectric Properties of Geological Materials: Implication for Soil 
Moisutre Detection by Means of Remote Sensing, IEEE Trans. Geosci. Remote Sens. 6 (2008) 16741688. doi:10.1109/TGRS.2008.916220.

[47] Y.Y. Li, K. Zhao, J.H. Ren, Y.L. Ding, L.L. Wu, Analysis of the dielectric constant of saline-alkali soils and the effect on radar backscattering coefficient: A case study of soda alkaline saline soils in western Jilin province using RADARSAT-2 data, Sci. World J. 2014 (2014). doi:10.1155/2014/563015.

[48] A. Delle Site, The vapour pressure of environmentally significant organic chemicals: a review of methods and data at ambient temperature, J. Phys. Chem. Ref. Data 26(1) (1997) 157-193.

[49] P.P. Falciglia, M.G. Giustra, F.G. a. Vagliasindi, Soil texture affects adsorption capacity and removal efficiency of contaminants in ex situ remediation by thermal desorption of diesel-contaminated soils, Chem. Ecol. 27 (2011) 119-130. doi:10.1080/02757540.2010.534087.

[50] J. Xu, A.G. Bravo, A. Lagerkvist, S. Bertilsson, R. Sjablom, J. Kumpiene, Sources and remediation techniques for mercury contaminated soil, Environ. Int. 74 (2014) 42-53. doi:10.1016/j.envint.2014.09.007.

[51] J. Wang, X. Feng, C.W.N. Anderson, Y. Xing, L. Shang, Remediation of mercury contaminated sites - A review, J. Hazard. Mater. 221-222 (2012) 1-18. doi:10.1016/j.jhazmat.2012.04.035.

[52] F. Ma, Q. Zhang, D. Xu, D. Hou, F. Li, Q. Gu, Mercury removal from contaminated soil by thermal treatment with $\mathrm{FeCl3}$ at reduced temperature, Chemosphere. 117 (2014) 388-393. doi:10.1016/j.chemosphere.2014.08.012.

[53] A.T. Reis, J.P. Coelho, I. Rucandio, C.M. Davidson, A.C. Duarte, E. Pereira, Thermodesorption: A valid tool for mercury speciation in soils and sediments?, Geoderma. 237 (2015) 98-104. doi:10.1016/j.geoderma.2014.08.019.

[54] M. Rumayor, M.A. Lopez-Anton, M. Díaz-Somoano, M.R. Martínez-Tarazona, A new approach to mercury speciation in solids using a thermal desorption technique, Fuel. 160 (2015) 525530. doi:10.1016/j.fuel.2015.08.028.

[55] J. Jachuła, D. Kołodyńska, Z. Hubicki, Sorption of $\mathrm{Zn}$ (II) and $\mathrm{Pb}$ (II) ions in the presence of the biodegradable complexing agent of a new generation, Chem. Eng. Res. Des. 90 (2012) 1671-1679. doi:10.1016/j.cherd.2012.01.015.

[56] R.W. Peters, Chelant extraction of heavy metals from contaminated soils., J. Hazard. Mater. 66 (1999) 151-210. doi:10.1016/S0304-3894(99)00010-2.

[57] C.N. Mulligan, Environmental applications for biosurfactants, Environ. Pollut. 133 (2005) 183-198. doi:10.1016/j.envpol.2004.06.009.

[58] A. Agarwal, Y. Liu, Remediation technologies for oil-contaminated sediments, Mar. Pollut. Bull. 101 (2015) 483-490. doi:10.1016/j.marpolbul.2015.09.010.

[59] A.M. Kunkel, J.J. Seibert, L.J. Elliott, R.L. Kelley, L.E. Katz, G.A. Pope, Remediation of Elemental Mercury Using, 40 (2004) 2384-2389.

[60] M. Anbia, S. Amirmahmoodi, Removal of $\mathrm{Hg}$ (II) and $\mathrm{Mn}$ (II) from aqueous solution using nanoporous carbon impregnated with surfactants, Arab. J. Chem. (2011). doi:10.1016/j.arabjc.2011.04.004.

[61] J.D. Subirés-Muñoz, A. García-Rubio, C. Vereda-Alonso, C. Gómez-Lahoz, J.M. Rodríguez-Maroto, F. García-Herruzo, J.M. Paz-García, Feasibility study of the use of different extractant agents in the remediation of a mercury contaminated soil from Almaden, Sep. Purif. Technol. 79 (2011) 151-156. doi:10.1016/j.seppur.2011.01.032.

[62] C.N. Mulligan, R.N. Yong, B.F. Gibbs, An evaluation of technologies for the heavy metal remediation of dredged sediments, J. Hazard. Mater. 85 (2001) 145-163. doi:10.1016/S03043894(01)00226-6. 
[63] Z. He, S. Siripornadulsil, R.T. Sayre, S.J. Traina, L.K. Weavers, Removal of mercury from sediment by ultrasound combined with biomass (transgenic Chlamydomonas reinhardtii), Chemosphere. 83 (2011) 1249-1254. doi:10.1016/j.chemosphere.2011.03.004.

[64] C. Comuzzi, B. Lesa, E. Aneggi, G. Dolcetti, D. Goi, Salt-assisted thermal desorption of mercury from contaminated dredging sludge, J. Hazard. Mater. 193 (2011) 177-182. doi:10.1016/j.jhazmat.2011.07.047.

[65] P.P. Falciglia, D. Malarbì, F.G.A. Vagliasindi, Electrochimica Acta Removal of mercury from marine sediments by the combined application of a biodegradable non-ionic surfactant and complexing agent in enhanced-electrokinetic treatment, Electrochim. Acta. 222 (2016) 1569-1577. doi:10.1016/j.electacta.2016.11.142.

[66] P.P. Falciglia, P. Scandura, F.G.A. Vagliasindi, Modelling and preliminary technical, energy and economic considerations for full-scale in situ remediation of low-dielectric hydrocarbon-polluted soils by microwave heating (MWH) technique, J. Soils Sediments. (2017). doi:10.1007/s11368-017$1682-8$. 


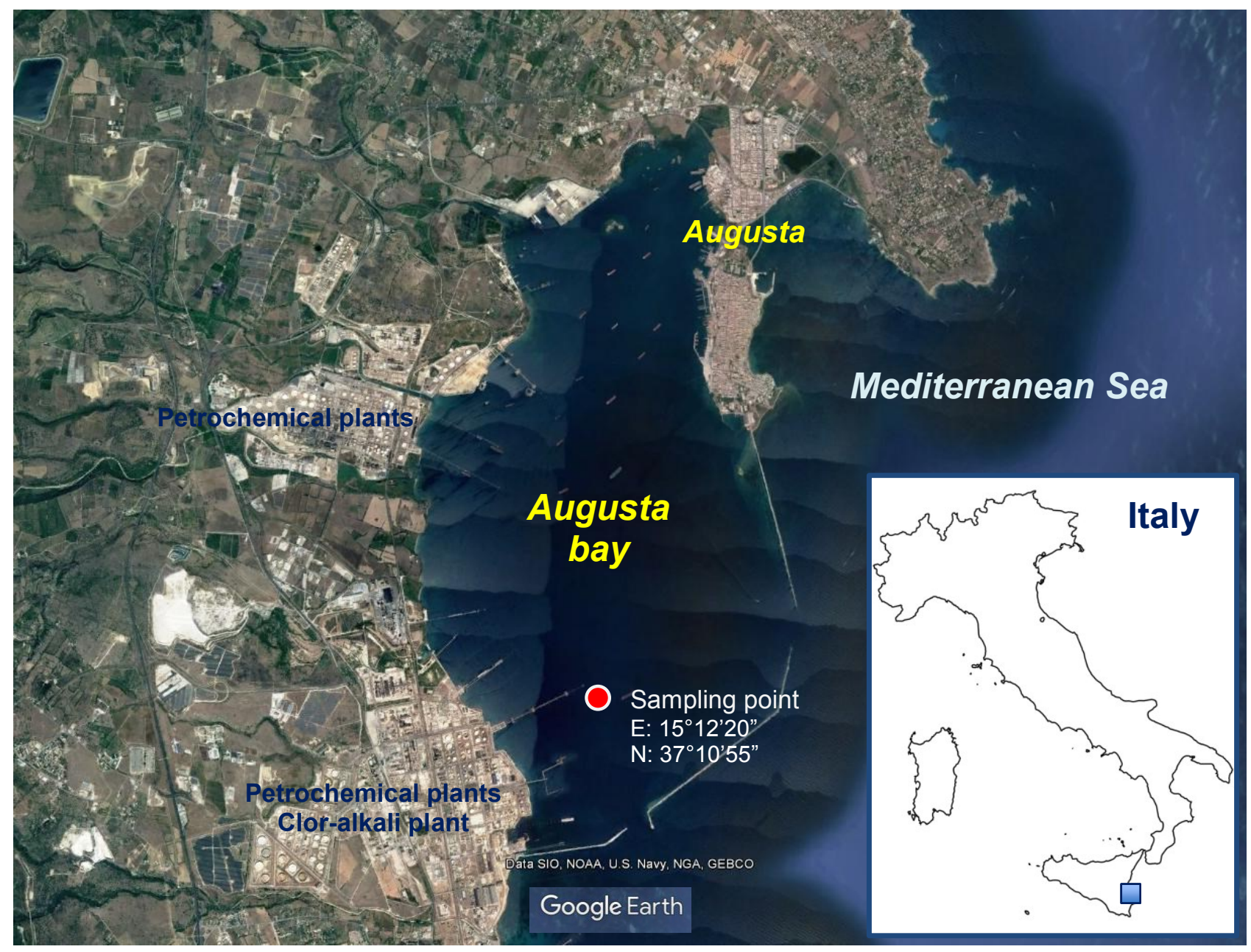

Figure 1. Augusta Bay (Italy) and location of the sediment sampling point (Google Earth ${ }^{\odot}$ ). 


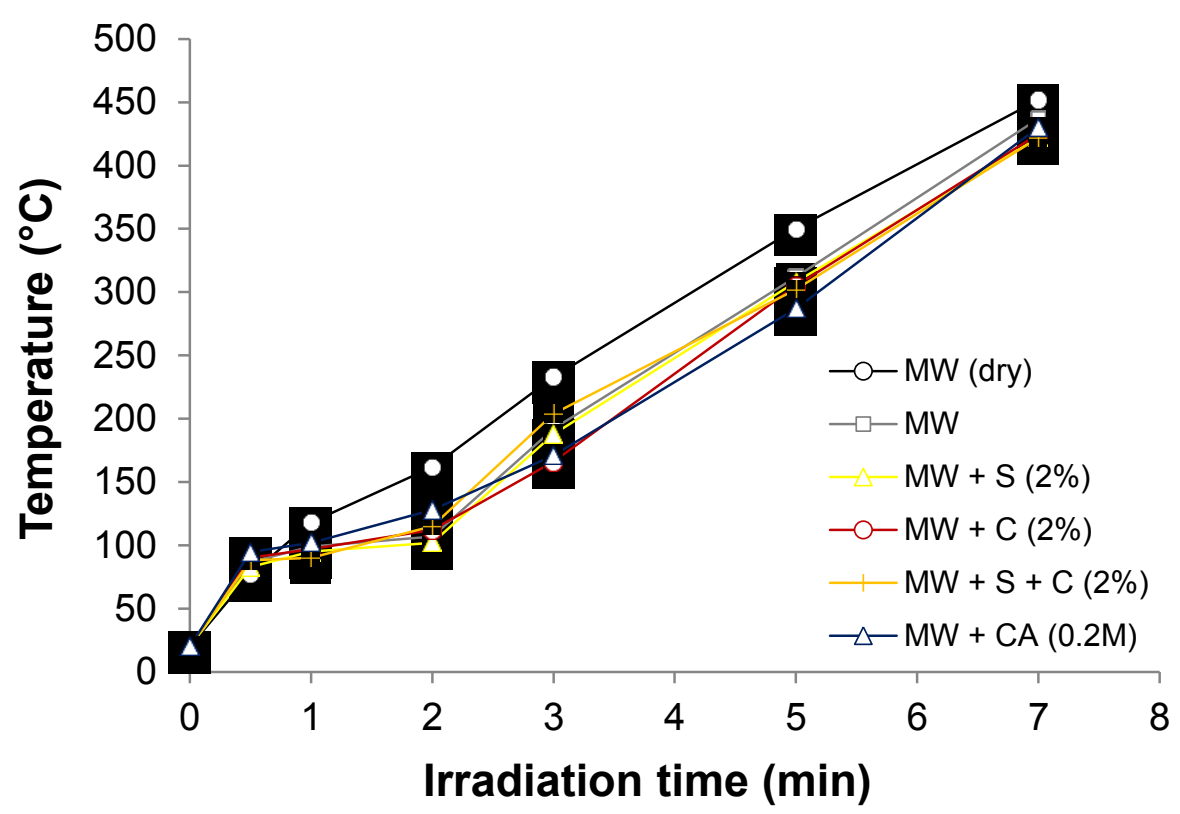

Figure 2. Sediment temperature variation as a function of the irradiation time for all the MWH treatments investigated.

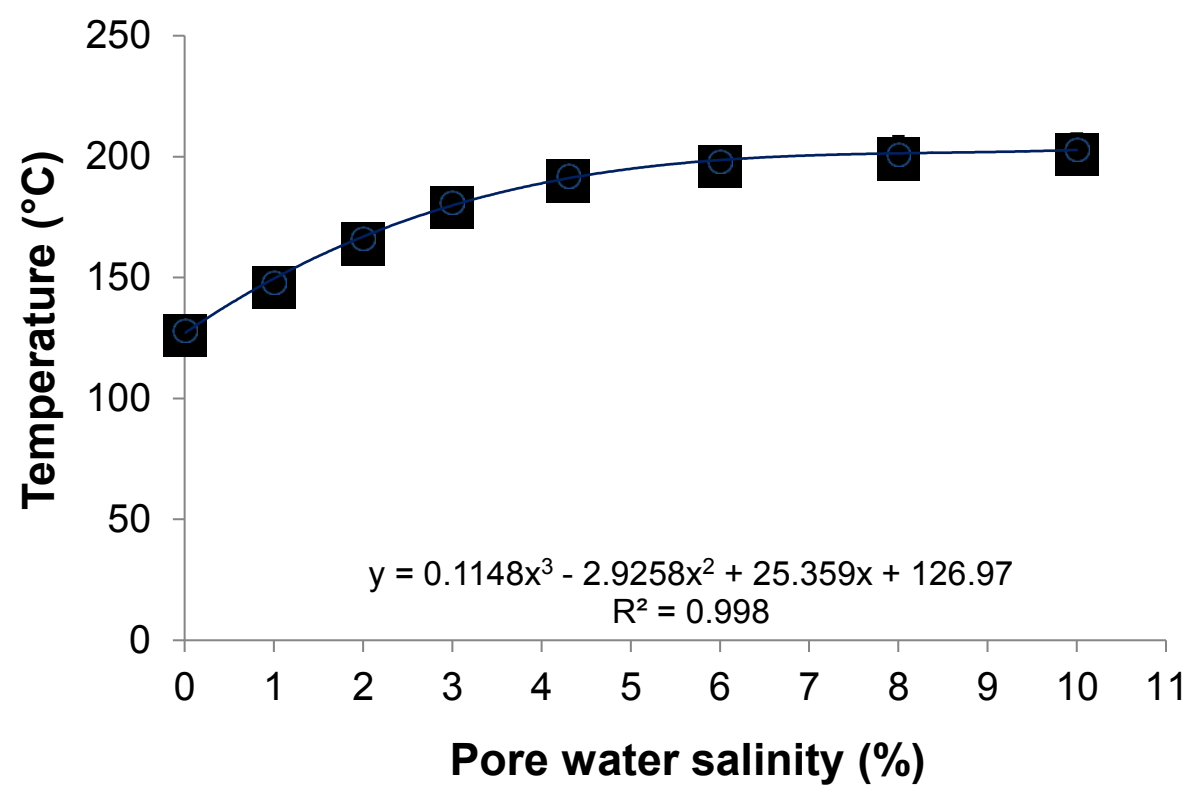

Figure 3. Sediment temperature variation as a function of the pore water salinity (MW treatment, irradiation time $=3 \mathrm{~min})$. 


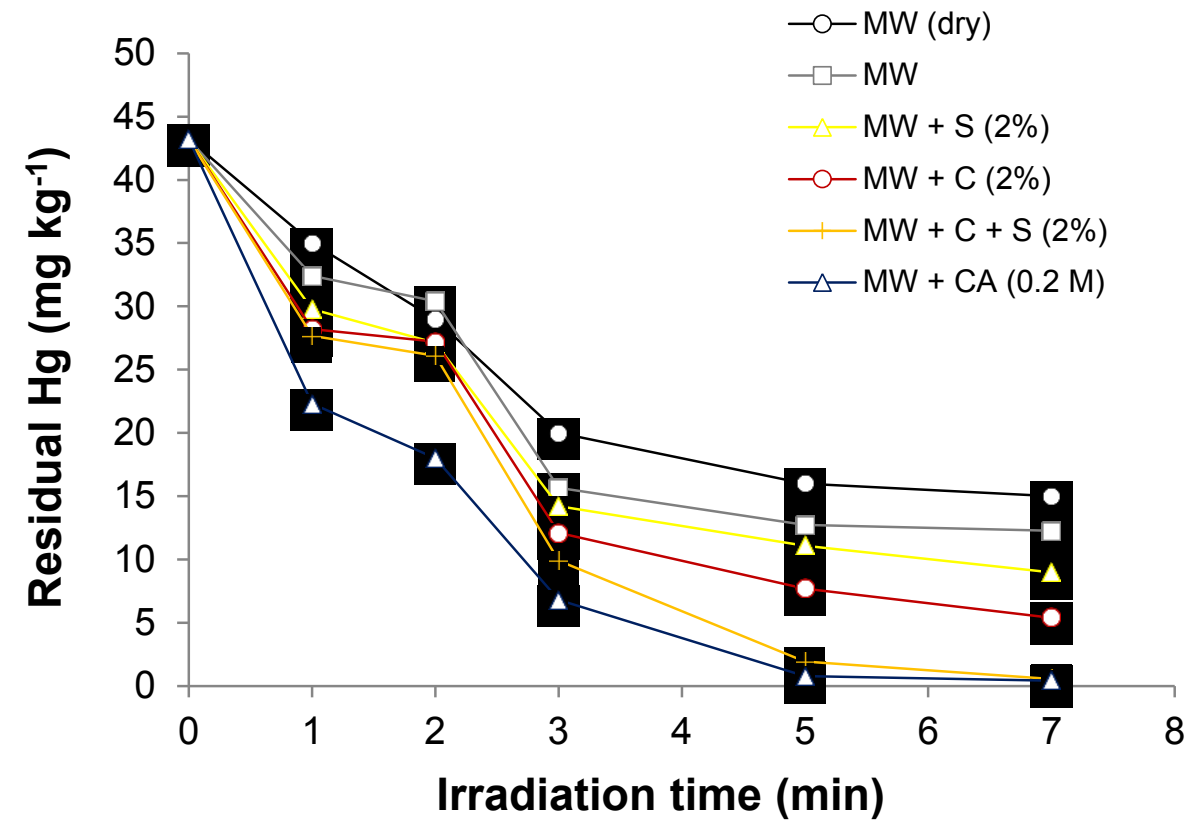

Figure 4. Hg residual concentration as a function of the irradiation time during all MWH treatments. 


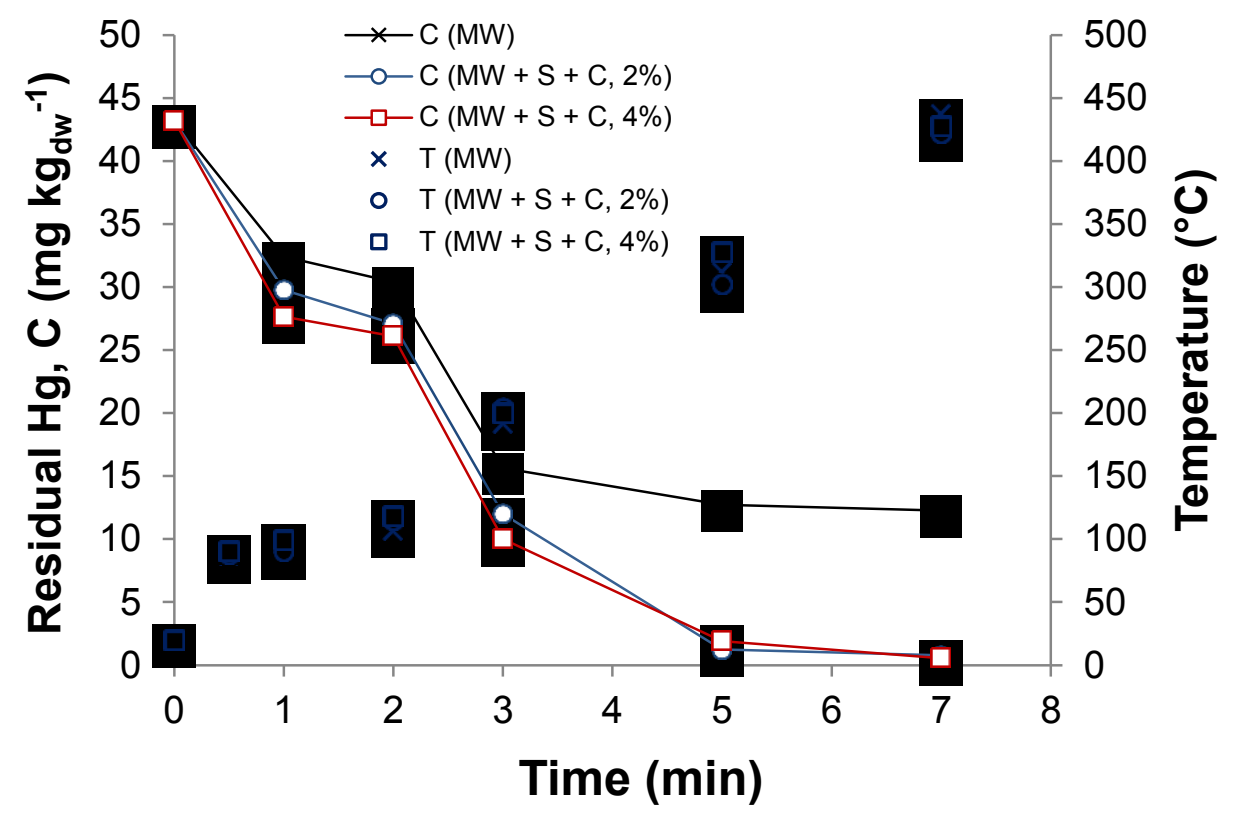

Figure 5. Influence of the enhancing agent dose (Tween ${ }^{\circledR} 80$ - MGDA mixture) on sediment temperature profiles and $\mathrm{Hg}$ removal kinetics in $\mathrm{MW}+\mathrm{S}+\mathrm{C}$ treatment (irradiation time $=3 \mathrm{~min}$; contact time $=60 \mathrm{~min}$ ).

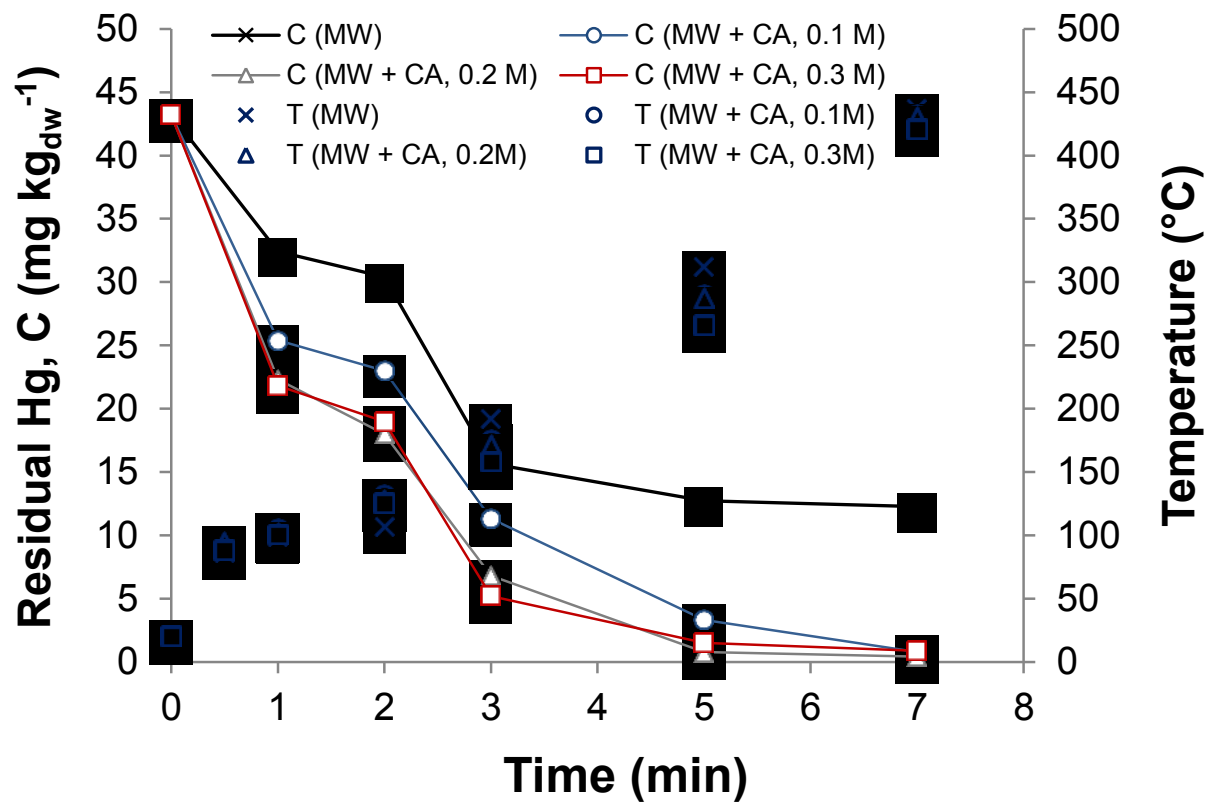

Figure 6. Influence of the enhancing agent dose (citric acid) on sediment temperature profiles and $\mathrm{Hg}$ removal kinetics in $\mathrm{MW}+\mathrm{CA}$ treatment (irradiation time $=3 \mathrm{~min}$; contact time $=60 \mathrm{~min}$ ). 


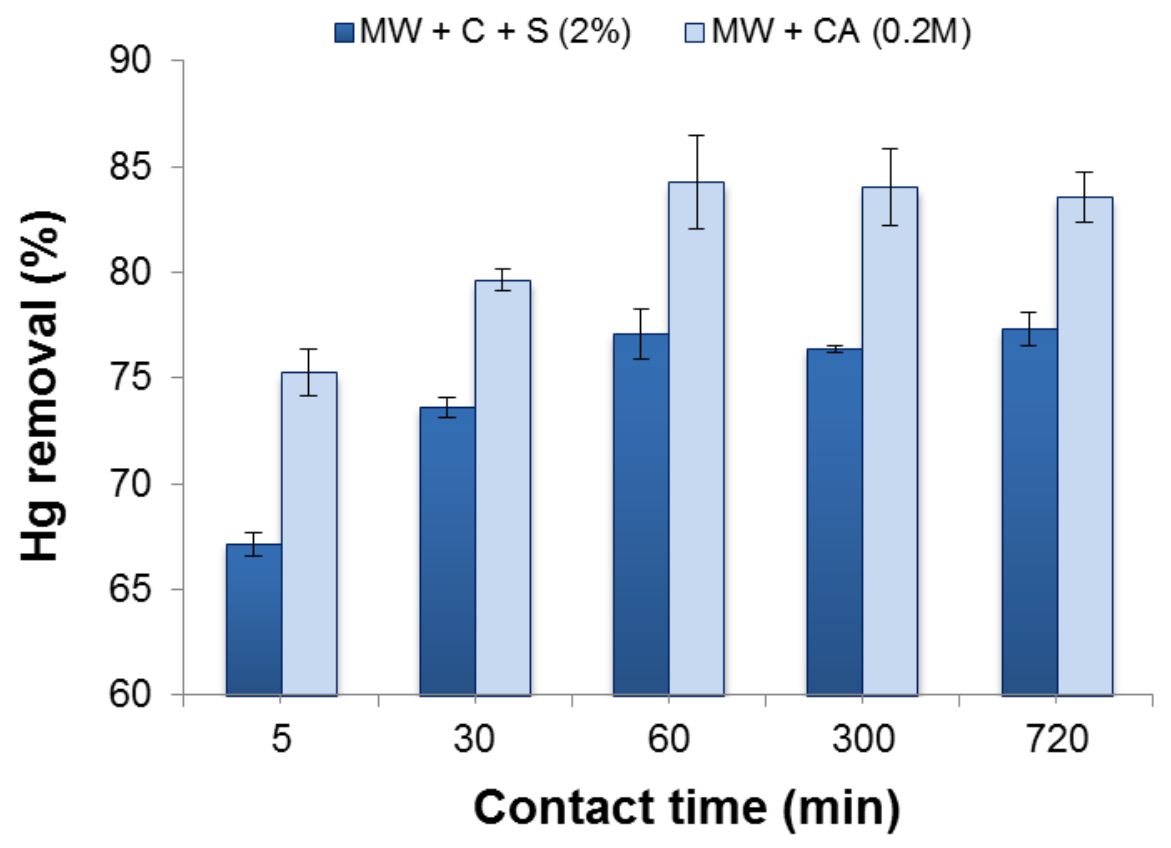

Figure 7. Influence of the contact time on $\mathrm{Hg}$ removal in $\mathrm{MW}+\mathrm{S}+\mathrm{C}$ and $\mathrm{MW}+\mathrm{CA}$ treatments (irradiation time $=3$ min; Tween ${ }^{\circledR} 80$ - MGDA mixture dose $=2 \%$; citric acid dose $=0.2 \mathrm{M}$ ). 
Table 1. Sequential extraction procedure with selected $\mathrm{Hg}$ fractions [4].

\begin{tabular}{lll}
\hline & \multicolumn{1}{c}{ Fraction } & \multicolumn{1}{c}{ Method } \\
\hline F1 & Soluble $\mathrm{Hg}$ & Deionised water $\left(100{ }^{\circ} \mathrm{C}\right)$. Exchangeable $\mathrm{Hg}: 1 \mathrm{M} \mathrm{C}_{2} \mathrm{H}_{3} \mathrm{NaO}_{2}$ \\
F2 & $\mathrm{Hg}$ bound to carbonates & $\mathrm{CH}_{3} \mathrm{COONa} / \mathrm{CH}_{3} \mathrm{COOH}(\mathrm{pH}=5)$ \\
F3 & $\mathrm{Hg}$ bound to Fe and $\mathrm{Mn}$ oxides & $\mathrm{NH}_{3}(\mathrm{OH}) \mathrm{Cl} 0.04 \mathrm{~mol} \mathrm{~L}^{-1}$ in $25 \% \mathrm{CH}_{3} \mathrm{COOH}\left(96^{\circ} \mathrm{C}\right)$ \\
F4 & Elemental $\mathrm{Hg}$ and $\mathrm{Hg}$ bound to organic & $\mathrm{Heating}\left(180{ }^{\circ} \mathrm{C}\right)(\mathrm{Hg}$ bound to organic matter $) ; 6 \mathrm{~mL} \mathrm{HNO}_{3}+$ \\
& matter & $1 \mathrm{~mL} 30 \% \mathrm{H}_{2} \mathrm{O}_{2}+\mathrm{MW}$ digestion $(\mathrm{Hg}$ bound to organic matter \\
& & + elemental Hg) \\
F5 & $\mathrm{Hg}$ bound to sulphides & $6 \mathrm{~mL} \mathrm{HCl}+\mathrm{HNO}_{3}(3: 1)+\mathrm{MW}$ digestion \\
\hline
\end{tabular}

Table 2. Experimental matrix.

\begin{tabular}{lcccc}
\hline Experiment & $\begin{array}{c}\text { Enhancing } \\
\text { agent }\end{array}$ & Concentration & $\begin{array}{c}\text { C : S } \\
\text { ratio }\end{array}$ & $\begin{array}{c}\text { Sample moisture } \\
(\%)\end{array}$ \\
\hline MW (dry) & - & - & - & 0 \\
MW & - & - & - & 42.2 \\
MW + C & MGDA & $2.0 \%$ & - & 42.2 \\
MW + S & Tween $^{\circledR} 80$ & $2.0 \%$ & - & 42.2 \\
MW + C + S (2\%) & MGDA, Tween $^{\circledR} 80$ & $2.0 \%$ & $1: 1$ & 42.2 \\
MW + C + S (4\%) & MGDA, Tween ${ }^{\circledR} 80$ & $4.0 \%$ & $1: 1$ & 42.2 \\
MW + CA (0.1M) & Citric acid & $0.1 \mathrm{M}$ & - & 42.2 \\
MW + CA (0.2M) & Citric acid & $0.2 \mathrm{M}$ & - & 42.2 \\
MW + CA (0.3M) & Citric acid & $0.3 \mathrm{M}$ & - & 42.2 \\
\hline MW = Microwave. & & & & \\
C = Chelate. & & & & \\
S = Surfactant. & & & & \\
MGDA = Methylglycinediacetic acid. &
\end{tabular}

Table 3. Physico - chemical properties of the sediments.

\begin{tabular}{lc}
\hline Physical properties & Value \\
\hline Density $\left(\mathrm{g} \mathrm{cm}^{-3}\right)$ & 2.37 \\
$\mathrm{pH}$ & 8.11 \\
Moisture content $(\%)$ & 42.2 \\
Organic matter $(\%)$ & 7.4 \\
Sulphides $\left(\mathrm{mg} \mathrm{kg}_{\mathrm{dw}}{ }^{-1}\right)$ & 43.6 \\
Salinity $(\%)$ & 4.3 \\
Dielectric constant $\left(\varepsilon^{\prime}\right)$ & 11.3 \\
Loss factor $\left(\varepsilon^{\prime \prime}\right)$ & 0.6 \\
\hline Main minerals & Percentage $(\%)$ \\
\hline Calcite & 70.5 \\
Quartz & 19.5 \\
Clay minerals & 8.8 \\
Other & 1.2 \\
\hline Heavy metals & Concentration $\left(\mathrm{mg} \mathrm{kg}_{\mathrm{dw}}{ }^{-1}\right)$ \\
\hline Hg & 43.2 \\
As & 8.2 \\
Cd & 0.4 \\
Cr tot & 49.2 \\
Ni & 29.8 \\
Pb & 28.8 \\
Cu & 51.4 \\
Zn & 88.2 \\
\hline Organic contaminants & 2.45 \\
\hline$\sum$ PAHs & 6.34 \\
TPHs &
\end{tabular}

Table 4. Residual moisture (\%) after different irradiation times for all treatments (initial sediment moisture $42.2 \%$ ). 


\begin{tabular}{lcccccc}
\hline Experiment & $0.5 \mathrm{~min}$ & $1 \mathrm{~min}$ & $2 \mathrm{~min}$ & $3 \mathrm{~min}$ & $5 \mathrm{~min}$ & $7 \mathrm{~min}$ \\
\hline MW & $31.6 \pm 1.2$ & $5.8 \pm 0.3$ & $1.1 \pm 0.1$ & $0.6 \pm 0.1$ & $0.0 \pm 0.0$ & $0.0 \pm 0.0$ \\
MW + C (2\%) & $36.1 \pm 0.7$ & $7.6 \pm 0.7$ & $2.7 \pm 0.4$ & $1.5 \pm 0.1$ & $0.0 \pm 0.0$ & $0.0 \pm 0.0$ \\
MW + S (2\%) & $35.2 \pm 1.3$ & $7.1 \pm 0.4$ & $2.5 \pm 0.2$ & $1.2 \pm 0.2$ & $0.0 \pm 0.0$ & $0.0 \pm 0.0$ \\
MW + C + S (2\%) & $32.1 \pm 2.1$ & $6.1 \pm 0.2$ & $1.5 \pm 0.2$ & $0.55 \pm 0.1$ & $0.0 \pm 0.0$ & $0.0 \pm 0.0$ \\
MW + C + S (4\%) & $34.2 \pm 2.4$ & $6.7 \pm 0.8$ & $2.9 \pm 0.7$ & $1.4 \pm 0.3$ & $0.0 \pm 0.0$ & $0.0 \pm 0.0$ \\
MW + CA (0.1M) & $33.4 \pm 1.2$ & $8.1 \pm 0.4$ & $2.1 \pm 0.2$ & $0.9 \pm 0.2$ & $0.0 \pm 0.0$ & $0.0 \pm 0.0$ \\
MW + CA (0.2M) & $34.7 \pm 1.6$ & $9.1 \pm 0.7$ & $1.4 \pm 0.3$ & $0.8 \pm 0.2$ & $0.0 \pm 0.0$ & $0.0 \pm 0.0$ \\
MW + CA (0.3M) & $34.6 \pm 1.1$ & $8.8 \pm 0.9$ & $1.6 \pm 0.1$ & $1.1 \pm 0.1$ & $0.0 \pm 0.0$ & $0.0 \pm 0.0$ \\
\hline
\end{tabular}

Table 5. Mercury concentration in sediment fractions by sequential extraction before and after MWH.

\begin{tabular}{|c|c|c|c|c|c|c|c|c|c|c|c|c|}
\hline \multirow[t]{2}{*}{ Fraction } & \multicolumn{2}{|c|}{$\begin{array}{c}\text { F1 } \\
\text { Labile }\end{array}$} & \multicolumn{2}{|c|}{$\begin{array}{c}\text { F2 } \\
\text { Carbonate }\end{array}$} & \multicolumn{2}{|c|}{$\begin{array}{c}\text { F3 } \\
\text { Oxides }\end{array}$} & \multicolumn{2}{|c|}{$\begin{array}{c}\mathrm{F} 4 \\
\text { Organic/ } \\
\text { Metallic } \\
\end{array}$} & \multicolumn{2}{|c|}{$\begin{array}{c}\text { F5 } \\
\text { Sulphides }\end{array}$} & \multicolumn{2}{|c|}{ Total } \\
\hline & $\begin{array}{c}\mathrm{mg} \\
\mathrm{kg}_{\mathrm{dw}^{-1}} \\
\end{array}$ & $\%$ & $\begin{array}{c}\mathrm{mg} \\
\mathrm{kg}_{\mathrm{dw}^{-1}} \\
\end{array}$ & $\%$ & $m g \operatorname{kg}_{d w}{ }^{-1}$ & $\%$ & $\mathrm{mg} \mathrm{kg} \mathrm{dw}^{-1}$ & $\%$ & $\mathrm{mg} \mathrm{kg} \mathrm{dw}^{-1}$ & $\%$ & $\mathrm{mg} \mathrm{kg} \mathrm{dw}^{-1}$ & $\%$ \\
\hline Untreated & $\begin{array}{c}0.48 \pm \\
0.07\end{array}$ & 1.1 & $\begin{array}{c}21.82 \pm \\
1.2\end{array}$ & 50.5 & $\begin{array}{c}0.78 \pm \\
0.03\end{array}$ & 1.8 & $\begin{array}{c}15.68 \pm \\
1.3\end{array}$ & 36.3 & $\begin{array}{c}4.45 \pm \\
0.3\end{array}$ & 10.3 & $\begin{array}{c}43.2 \pm \\
2.2\end{array}$ & 100.0 \\
\hline MW & $\begin{array}{c}0.05 \pm \\
0.1 \\
\end{array}$ & 0.4 & $\begin{array}{c}3.33 \pm \\
0.4 \\
\end{array}$ & 27.2 & $\begin{array}{c}0.44 \pm \\
0.05 \\
\end{array}$ & 3.6 & $\begin{array}{c}4.42 \pm \\
0.5 \\
\end{array}$ & 36.1 & $\begin{array}{c}4.02 \pm \\
0.7 \\
\end{array}$ & 32.8 & $\begin{array}{c}12.26 \pm \\
1.3 \\
\end{array}$ & 100.0 \\
\hline $\mathrm{MW}+\mathrm{C}(2 \%)$ & $\begin{array}{c}0.00 \pm \\
0.0 \\
\end{array}$ & 0.0 & $\begin{array}{c}0.33 \pm \\
0.02 \\
\end{array}$ & 6.0 & $\begin{array}{c}0.20 \pm \\
0.03 \\
\end{array}$ & 3.7 & $\begin{array}{c}4.01 \pm \\
0.6 \\
\end{array}$ & 73.3 & $\begin{array}{c}0.93 \pm \\
0.03 \\
\end{array}$ & 17.0 & $\begin{array}{c}5.47 \pm \\
0.6 \\
\end{array}$ & 100.0 \\
\hline $\mathrm{MW}+\mathrm{S}(2 \%)$ & $\begin{array}{c}0.00 \pm \\
0.0 \\
\end{array}$ & 0.0 & $\begin{array}{c}2.68 \pm \\
0.3 \\
\end{array}$ & 29.9 & $\begin{array}{c}0.52 \pm \\
0.06 \\
\end{array}$ & 5.8 & $\begin{array}{c}1.44 \pm \\
0.05 \\
\end{array}$ & 16.1 & $\begin{array}{c}4.33 \pm \\
0.05 \\
\end{array}$ & 48.3 & $\begin{array}{c}8.97 \pm \\
0.7 \\
\end{array}$ & 100.0 \\
\hline $\mathrm{MW}+\mathrm{C}+\mathrm{S}(2 \%)$ & $\begin{array}{c}0.00 \pm \\
0.0\end{array}$ & 0.0 & $\begin{array}{c}0.00 \pm \\
0.0\end{array}$ & 0.0 & $\begin{array}{c}0.00 \pm \\
0.0\end{array}$ & 0.0 & $\begin{array}{c}0.10 \pm \\
0.05\end{array}$ & 17.9 & $\begin{array}{c}0.46 \pm \\
0.03\end{array}$ & 82.1 & $\begin{array}{c}0.56 \pm \\
0.02\end{array}$ & 100.0 \\
\hline $\mathrm{MW}+\mathrm{CA}(0.2 \mathrm{M})$ & $\begin{array}{c}0.00 \pm \\
0.0 \\
\end{array}$ & 0.0 & $\begin{array}{c}0.00 \pm \\
0.0 \\
\end{array}$ & 0.0 & $\begin{array}{c}0.00 \pm \\
0.0 \\
\end{array}$ & 0.0 & $\begin{array}{c}0.00 \pm \\
0.0 \\
\end{array}$ & 0.0 & $\begin{array}{c}0.43 \pm \\
0.01 \\
\end{array}$ & 100.0 & $\begin{array}{c}0.43 \pm \\
0.08\end{array}$ & 100.0 \\
\hline
\end{tabular}

